\title{
Aspects of Orchidaceae distribution in Costa Rica and northwestern South America: a study on similarity with emphasis on the Amazonian Region
}

\author{
Edlley Max Pessoa ${ }^{1,3}$, Ivo Abraão Araújo da Silva² and Marccus Alves ${ }^{1}$
}

Received: 22.11.2013; accepted: 27.05.2014

\begin{abstract}
Aspects of Orchidaceae distribution in Costa Rica and northwestern South America: a study on similarity with emphasis on the Amazonian Region). The purpose of this study was to compare the floristic composition of Orchidaceae among different areas of Costa Rica and northwestern South America, aiming to answer the following questions: 1) Is the variation in the species composition among the study areas better explained by physical features, geographical closeness, or potential endemism centers? 2) Does the floristic similarity decay with geographical distance? We selected 11 surveys conducted in South America and two in Central America (Costa Rica). Cluster analysis was conducted using the software MVSP. The result was a split pattern between Amazonian and non-Amazonian floristic compositions. The environmental conditions analyzed appear to be important factors in explaining the orchid composition of areas outside the Amazon basin. The Amazonian group is environmentally very uniform, but floristically very distinct, and no physical features were determinant of the internal segregation into two subgroups. Geographic closeness has no influence on the species composition of the areas, and historical factors may explain the pattern observed.
\end{abstract}

Keywords: Biogeography, Brazil, Colombia, Costa Rica, Neotropics, Venezuela

RESUMO - (Distribuição de Orchidaceae na Costa Rica e Noroeste da América do Sul: um estudo de similaridade com ênfase na Região Amazônica). O objetivo desse estudo foi comparar a composição florística de Orchidaceae de diferentes áreas da Costa Rica e Noroeste da América do Sul, visando responder as questões: 1) A variação da composição de espécies entre as áreas estudadas é melhor explicada por características físicas, proximidade geográfica, ou potenciais centros de endemismo? 2) A similaridade florística diminui com a distância geográfica? Nós selecionamos 11 inventários realizados na América do Sul, e mais dois na América Central (Costa Rica). A análise de agrupamento foi produzida usando o software MVSP. O resultado foi um padrão de segregação entre as composições florísticas de áreas Amazônicas e não Amazônicas. As condições ambientais analisadas parecem ser importantes fatores para explicar a composição de orquídeas de áreas extra Amazônicas. O grupo amazônico é ambientalmente uniforme, mas floristicamente muito distinto, e nenhuma característica física foi determinante para a segregação interna em dois sub-grupos. Proximidade geográfica não teve influencia sobre a composição de espécies das áreas, e fatores históricos podem explicar esse padrão observado.

Palavras chave: Biogeografia, Brasil, Colômbia, Costa Rica, Região Neotropical, Venezuela

\section{Introduction}

Orchidaceae is one of the most diverse families of angiosperms with ca. 25,500 species (Dressler 2005) and 800 genera (Dressler 1993). Orchids are widely distributed (Christenson 2004), although their diversity center is in the tropics, especially in the Indo-Malayan region and Neotropics (Dressler 1993), in which we highlight Brazil, Colombia, Ecuador and Peru as the richest countries in Orchidaceae species (Dressler 1981). The family is also very well represented in the Brazilian Atlantic Forest (Stehmann et al. 2009) as well as in the Amazon Forest (Ribeiro 1999, Funk \& Hollowell 2007).

The homogeneous seed wind-dispersal mechanism in the family, turn the dispersion process completely independent of animals, and it makes orchids a good case for distribution studies. The distribution patterns may be explained by ecological, geographical or historical factors (Trejo-Torres \& Ackerman 2001),

1. Universidade Federal de Pernambuco, Laboratório de Morfo-Taxonomia Vegetal, Departamento de Botânica 50670-901, Recife, PE, Brasil

2. Universidade Federal de Pernambuco, Laboratório de Pteridófitas, Departamento de Botânica, 50670-901 Recife, PE, Brasil

3. Corresponding author: edlley_max@hotmail.com 
and it is not linked to animal distribution such as birds or mammals species.

Northwestern South America is characterized by a large diversity of ecosystems, among which are the Amazon forest, the Amazon Cerrado (Campinaras or Lavrados), the Tepui vegetation, the Páramos, the Chocó and the Llanos (Daly \& Mitchell 2000). The Amazon Forest is the largest plant formation in the area, located in the Amazon river basin, and comprises mainly lowland forests (Ab'Sáber 2006). The large area of evergreen moist forest mistakenly suggests homogeneous vegetation. However, up to now it is known that it is a mosaic of ecosystems and includes several centers of endemism (Silva et al. 2005), with islands of open vegetation (Daly \& Mitchell 2000).

Studies with vertebrates (Haffer \& Prance 2001), butterflies (Hall \& Harvey 2002), and woody plants (Prance 1982) have suggested the occurrence of distinct centers of endemism within the Amazon Forest. However, herbaceous and epiphytic species have never been used to test this biogeographic hypothesis.

Therefore, the present study was aimed at comparing the floristic composition of Orchidaceae among different areas of Costa Rica and northwestern South America in order to answer the questions: 1) Is the variation in the species composition among the studies areas better explained by physical features (elevation, precipitation, temperature, presence of rock outcrops and vegetation), geographical closeness, or potential endemism centers? 2) Does the floristic similarity decay with geographical distance?

\section{Material and methods}

Distribution data - Surveys already published or in press focused on Orchidaceae and conducted in the area of interest were selected for the analysis (table 1, figure 1). The main selection criterion was the accuracy of taxonomic identification of orchids. Consequently, we selected 11 areas from northwestern South America, and two from Central America (Costa Rica). This study avoided the inclusion of online data available from herbarium collections due to the usual problems with taxonomic identification. It often compromises wide studies in biogeography, conservation and phylogeny (Kury et al. 2006, Iganci \& Morim 2012).

The number of available surveys included in our selection criteria is small, and there are significant differences between the sizes of the studied areas, these limitations make preliminary the conclusions of this study. We recognize that these factors could interfere in the analysis, however this study provides the first data about distribution of orchids in northwestern South America and Costa Rica by using current knowledge of the local flora. The increase in the number of areas could lead to more effective results regarding the floristic similarities between Central and South America.

Taxonomic Adjustments - In recent years profound taxonomic changes have been proposed for Orchidaceae, especially related to generic circumscription. Due to the different times of publication of the surveys selected for this study, they followed different taxonomic classifications. Thus, prior to performing any analysis, a careful updating of the names used for each survey selected was mandatory.

Generally speaking, for this study, Pleurothallidinae are treated according to Pridgeon \& Chase (2001); Gomesa R. Br. includes some species of Oncidium Sw. according to Chase et al. (2009); Maxillaria Ruiz \& Pav. is segregated according to Blanco et al. (2007); Scaphyglottis Poepp. \& Endl. is considered under Dressler et al.'s (2004) circumscription; and Trichocentrum Poepp. \& Endl. is considered according to Braem (1993), Pupulin (1995) and Christenson (1999).

Synonyms and valid species names were standardized according to The Plant List database.

Study Areas - The areas chosen (13) are located in the Neotropics. Two of them are in Central America (Costa Rica), the others in South America. Three of the South American areas are outside the limits of the Amazon forest: the Chocó, on the Pacific coast of Colombia, and two areas near the Venezuelan Caribbean Coast (figure 1).

The Amazon Basin combines eight selected areas which are distributed in Brazil (seven) and French Guyana (one). Based upon the Centers of Endemism published by Silva et al. (2005), those areas can be placed in four of these centers - Inambari (IEC), Guyana (GEC), Xingú (XEC) and Belém (BEC).

The selected areas include a large variation in altitude, ranging from lowland forests (Ilha do Combu, $10 \mathrm{~m}$ mid-elev.) to highland forests (Chocó, 1,400 m mid-elev.). Furthermore, they include open vegetation such as Llanos in Venezuela, Campinaranas in Brazil, and also dense forest.

Data Analysis - A database of species consisting of a binary (presence $\times$ absence) matrix based on the thirteen surveys previously selected was built. 
Table 1. Analysed areas, with country, geographical coordinates, number of orchid species, and reference.

\begin{tabular}{|c|c|c|c|c|c|}
\hline Abbreviation & Area name & Country & Geographic Coordinates & $\begin{array}{l}\text { Species } \\
\text { number }\end{array}$ & Reference \\
\hline $\mathrm{ACB}$ & Estado do Acre & Brazil & $10^{\circ} 07^{\prime} \mathrm{S}$ and $69^{\circ} 21^{\prime} \mathrm{W}$ & 55 & Christenson, 2008 \\
\hline AND & Serra das Andorinhas & Brazil & $06^{\circ} 10^{\prime} \mathrm{S}$ and $48^{\circ} 35^{\prime} \mathrm{W}$ & 69 & Atzingen et al., 1996 \\
\hline $\mathrm{BHC}$ & Parque Nacional Barra Honda & Costa Rica & $10^{\circ} 10^{\prime} \mathrm{N}$ and $85^{\circ} 21^{\prime} \mathrm{W}$ & 24 & $\begin{array}{l}\text { Borarín \& Pupulin, } \\
2007\end{array}$ \\
\hline CArB & Serra de Carajás & Brazil & $05^{\circ} 54^{\prime} \mathrm{S}$ and $48^{\circ} 25^{\prime} \mathrm{W}$ & 98 & Silveira et al., 1995 \\
\hline $\mathrm{CAxB}$ & Flona Caxiuanã & Brazil & $01^{\circ} 42^{\prime} \mathrm{S}$ and $51^{\circ} 31^{\prime} \mathrm{W}$ & 33 & Koch et al., 2014 \\
\hline $\mathrm{COB}$ & Ilha do Combu & Brazil & $01^{\circ} 25^{\prime} \mathrm{S}$ and $48^{\circ} 25^{\prime} \mathrm{W}$ & 40 & Cardoso et al., 1996 \\
\hline $\mathrm{CHC}$ & Departamento do Chocó & Colombia & $05^{\circ} 29^{\prime} \mathrm{N}$ and $77^{\circ} 10^{\prime} \mathrm{W}$ & 76 & $\begin{array}{l}\text { Gutiérrez \& Mosquera, } \\
2006\end{array}$ \\
\hline CUV & Serranía de La Cuchila & Venezuela & $10^{\circ} 07^{\prime} \mathrm{N}$ and $63^{\circ} 33^{\prime} \mathrm{W}$ & 47 & Leopardi, 2010 \\
\hline $\begin{array}{l}\text { DUB } \\
\text { QUC }\end{array}$ & $\begin{array}{l}\text { Reserva Ducke } \\
\text { Parque Nacional Manuel } \\
\text { Antonio, Quepos }\end{array}$ & $\begin{array}{c}\text { Brazil } \\
\text { Costa Rica }\end{array}$ & $\begin{array}{l}03^{\circ} 00^{\prime} \mathrm{S} \text { and } 59^{\circ} 52^{\prime} \mathrm{W} \\
9^{\circ} 21^{\prime} \mathrm{N} \text { and } 84^{\circ} 06^{\prime} \mathrm{W}\end{array}$ & $\begin{array}{l}68 \\
39\end{array}$ & $\begin{array}{l}\text { Ribeiro, } 1999 \\
\text { Pupulin } 1998\end{array}$ \\
\hline SFG & Departamento de Saul & $\begin{array}{l}\text { French } \\
\text { Guyana }\end{array}$ & $03^{\circ} 30^{\prime} \mathrm{N}$ and $53^{\circ} 28^{\prime} \mathrm{W}$ & 122 & Christenson, 1997 \\
\hline SUV & Estado do Sucre & Venezuela & $10^{\circ} 38^{\prime} \mathrm{N}$ and $63^{\circ} 02^{\prime} \mathrm{W}$ & 121 & $\begin{array}{l}\text { Leopardi \& Cumana, } \\
2008\end{array}$ \\
\hline VIB & Parque Nacional do Viruá & Brazil & $01^{\circ} 42^{\prime} \mathrm{N}$ and $61^{\circ} 10^{\prime} \mathrm{W}$ & 65 & Pessoa, 2013 \\
\hline
\end{tabular}

The relationship among the biological variable richness and mid-elevation, average temperature, vegetation and precipitation of each study site was analyzed according to Generalized Linear Models (GLM) (McCulloch \& Searle 2001) generated in the program Statistica 7.0 (StatSoft 2004). The GLMs test for a series of relationships between the dependent and independent variables and manage the data using link functions and exponential family (e.g., normal, Poisson or binomial) distributions (Baldwin and Bradfield 2007, Bolker et al. 2008).

Response variables were transformed to improve the linearity and homogeneity of the variance, so that the GLMs could be applied based on a normal distribution in some situations. Thus, the values of the mid-elevation and precipitation variables were transformed into $\log 10$ to obtain normality of the data and homogeneity of variances. In all cases, values of $p \leq 0.05$ were considered significant.

A cluster analysis was conducted to compare similarities in species composition among the study areas, quantified with the Jaccard index (Legendre \& Legendre 1998) using UPGMA (Unweighted Pair-Group Method using Arithmetic Averages) as a clustering algorithm (Sneath \& Sokal 1973) according to MVSP 3.1 (multivariate statistical package program) (Kovach 2000). This type of analysis is suitable for the presence-absence data available in this study, and the Jaccard index determines the proportion of species shared by a pair of sites in relation to the total number of species present in these sites.
The Jaccard indices and geographical distances among sites were evaluated through the application of a simple linear regression, performed by using the Statistica 7.0 (StatSoft 2004). The regression analysis was performed to test the hypothesis that species similarity decays with geographical distance since environmental conditions are always spatially auto-correlated, so that nearby sites tend to be more similar in their environmental conditions than distant sites (Legendre 1993).

In order to analyze the variation of species composition per area related to environmental variables (mid-elevation, average temperature, vegetation, precipitation and rock outcrop), we used the Canonical Correspondence Analysis (CCA), a multivariate technique that evaluates the patterns of co-variation among groups of species and a series of site variables (Ter Braak 1987). The CCA was conducted on species composition-environmental variables matrices using the software MVSP 3.1 (Kovach 2000).

Whenever necessary, the data were transformed to meet the assumptions of normality and heterogeneity of variances. Therefore, the values of the mid-elevation and precipitation variables were transformed into $\log 10$ to obtain normality of the data and homogeneity of variances. In all cases, values of $p \leq 0.05$ were considered significant.

\section{Results}

From the total number of species (525) included in the analysis, 185 (35\%) were shared by at least two 
areas, and about $65 \%$ were restricted to a single area. Few species (14, about $2.7 \%$ ) were widely distributed and found in at least half of the areas included in the present study.

The total complement of species belong to 153 genera, the most representative ones being Epidendrum L. (54 spp.), Habenaria Willd. (18 spp.), Catasetum Rich ex Kunth (14 spp.), and Sobralia Ruiz \& Pav. (12 spp.). Nevertheless, 61 genera were represented by only one species.

Furthermore, Campylocentrum micranthum (Lindl.) Rolfe, Dimerandra emarginata (G. Mey.) Hoehne, Epidendrum nocturnum Jacq., E. strobiliferum Rchb.f. and Rodriguezia lanceolata Ruiz \& Pav. were the most frequent species in the analyzed lists as they have been found in around $70 \%$ of the areas.

Based on the GLMs test, mid-elevation could explain the variation of richness $(F=6.05$ and $p=0.04$ ) (figure 2). Conversely, the independent variables average temperature $(F=3.26$ and $p=0.11)$, vegetation $(F=1.02$ and $p=0.40)$, and precipitation $(F=1.51$ and $p=0.25)$ did not generate any significant effect on the richness values.

The cluster analysis results showed a split pattern between the Amazonian and extra-Amazonian orchid diversity composition (figures 3-4). The areas located in the Amazon Basin emerge together as a group with

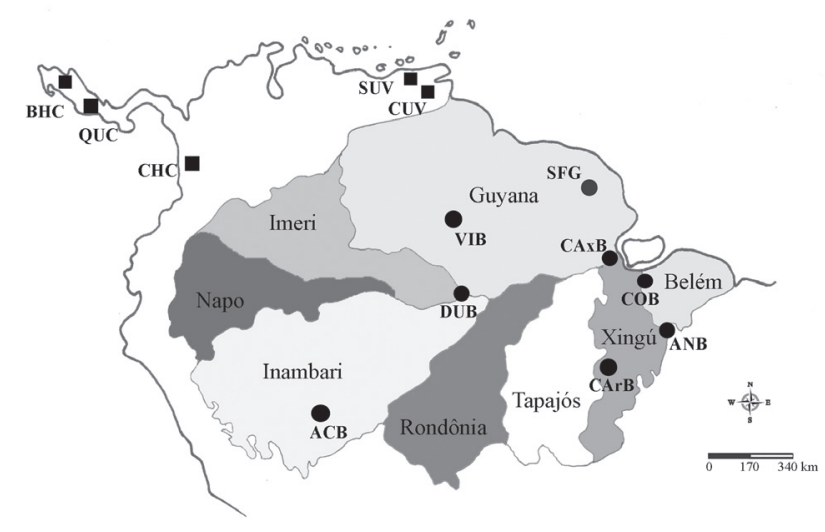

Figure 1. Map of the distribution of the areas analyzed in this study and Amazonian endemism centers. ACB: Acre (Brazil); ANB: Serra das Andorinhas (Brazil); BHC: Barra Honda National Park (Costa Rica); CArB: Serra de Carajás (Brazil); CAxB: Floresta Nacional Caxiuanã (Brazil); COB: Ilha do Combu (Brazil); CHC: Chocó (Colombia); CUV: Serranía Cuchila (Venezuela); DUB: Reserva Ducke (Brazil); QUC: Quepos National Park (Costa Rica); SFG: Saül (French Guyana); SUV: Sucre (Brazil); VIB:Viruá National Park (Brazil). about $10 \%$ similarity basis, reaching a maximum of $38 \%$ between Serra de Carajás (CArB) and Serra das Andorinhas (AND) (both located in the State of Pará, Brazil).

Extra-Amazonian areas are arranged in three different groups. The first one consists of areas from Costa Rica, the second one is formed by a single area (Chocó, Colombia), and the third one combines Venezuelan areas.

The linear regression test (LRT) shows that the geographic closeness of the studied areas has no influence on the species composition arrangement $\left(R^{2}=-0.06\right.$ and $\left.p=0.56\right)$.

According to the canonic correspondence analysis (CCA), the environmental physical features analyzed were partially determinant of the species composition variation among the studied areas. The analysis shows five significant axes, with cumulative percentage of explanation for $46.7 \%$ of the observed variation. It suggests that part of the variation in species composition found is actually affected by other factors which were not included in the present analysis.

Figure 5 shows the results from the two first axes (eigenvalues: Axis $1=0.73$ and Axis $2=0.67$; Canonic correlation: Axis $1=0.99$ and Axis $2=0.98$ ). In the first axis, the extra-Amazonian group formed by Chocó (CHC) (Colombia), Barra Honda (BHC) and Quepos (QUC) (both located in Costa Rica) shared similar species composition. This could be explained by shared physical attributes such as vegetation, temperature, precipitation and elevation. The Amazonian group and the Venezuelan areas are probably affected by the occurrence of rock outcrops. Moreover, the observation of Axis 2 shows that the distinction of the two cited groups is possibly related to the variation in elevation and precipitation.

\section{Discussion}

The present study showed that the South American areas studied are related concerning the species composition of orchids. It contradicts previous theories by Cracraft \& Prum (1988), Amorim \& Pires (1996), Morrone (2004, 2006) and Quijano-Abril et al. (2006) who pointed out the close relationship between the species composition of the Chocó (CHC) (Colombia) and continental Central America (Darién province). The Andean uplift could be the main reason to segregate the northern South America lowland forest, whereas Pacific areas such as the Chocó remain in contact with the Central America and the Caribbean 
flora (Gentry 1982, Franco-Rosselli \& Berg 1997, Hooghiemstra \& Hammen 2001).

The wind-dispersal mechanism of the Orchidaceae diaspora would provide the possibility of long-distance dispersal (Gentry \& Dodson 1987). Cross-Andean dispersal has been also observed in Euglossini bees (Dick et al. 2004), a group of insects strictly related to orchid pollination (Van der Pijl \& Dodson 1966). Both factors could explain the disjunct pattern (ChocóAmazon) found in our analysis.

The two areas of the Venezuelan Caribbean Coast included in this study represent a distinct bio-geographic province called the Coastal Cordillera by Daly \& Michell (2000) or Venezuelan Coast by Morrone (2006). They emerge as an independent group, but related with the Amazon cluster. Both areas, based on Pennington et al. (2000), share a distinct physiognomy from the Amazon, as coastal vegetation, highland humid forest and seasonal forests. The CCA also showed that rock outcrops (axis 2) would be the main physical feature to distinguish them from the Amazon portion. Trejo-Torres \& Ackerman (2001) also suggested a close floristic relationship among the Venezuelan coast and Caribbean areas (Lesser Antilles). It helps to understand the position of the group in the cluster.

The dry Llanos vegetation between the Venezuelan coast and the wet Amazon forest (Pennington et al. 2000) could represent an ecological barrier to dispersal for several species. However, it seems to be less effective than the Andes, since the Venezuelan areas used in this study emerge as a sister group of the Amazon areas with around 5\% similarity.

The Amazonian area group shares similar environmental conditions as shown by the CCA

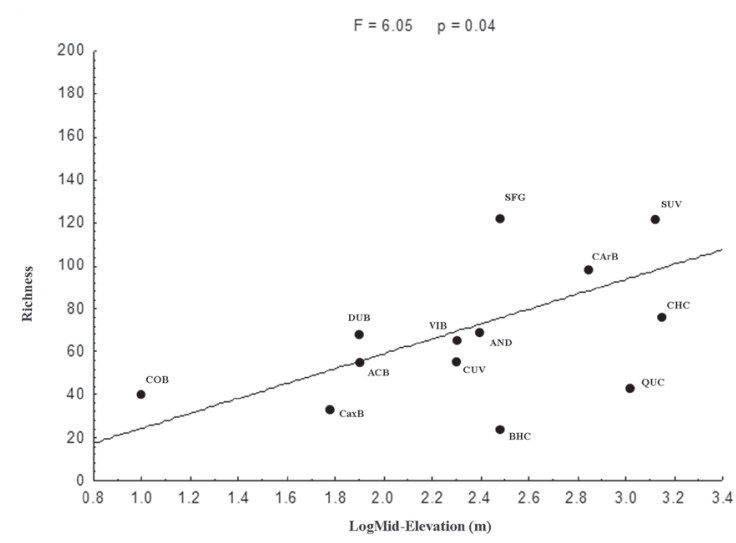

Figure 2. Effects of the mid-elevation on the richness of species in northwestern South America and Costa Rica. analysis, with no physical variables to explain the two subgroups formed in the cluster analysis (figures 3, 4).

The first subgroup includes the two areas in the Inambari Center of Endemism [Reserva Ducke (DUB) and Acre, (ACB) and Saül (SFG) (French Guyana), which is part of the Guyana Center of Endemism (GEC). Although the two Inambari areas have a large geographical distance (LRT: geographical closeness is not relevant), the huge similarity found in the composition of orchid diversity may be explained by historical factors [Endemism Center, according Silva et al. (2005)]. Nonetheless, there is no clear explanation available from the methods used to explain the occurrence of Saül (SFG) in this group. Even so, a similar distribution pattern between areas located in the Center of Endemism of Inambari and Guyana was found for some species of frogs (Garda \& Cannatella 2007).

The other Amazon subgroup is formed by two areas included in the Center of Endemism Guyana (CEG) [Viruá (VIB) and Caxiuanã (CaxB)] and three areas in the Center of Endemism Xingú (CEX) [Ilha do Combu (COB), Serra de Carajás (CArB) and Serra das Andorinhas (AND)], some of them located on the border of the Center of Endemism Belém (CEB).

The analysis corroborates in part with the biogeographic hypothesis presented by Cracraft \& Prum (1988) and Amorim (2001) for the Amazon Basin, in which such authors proposed historical relationships among the three Centers of Endemism (GEC, XEC and BEC) based on cladistic biogeography. However, Viruá (VIB) and Caxiuanã (CaxB), despite belonging to the same Center of Endemism as assumed by Silva et al. (2005), do not emerge together. This

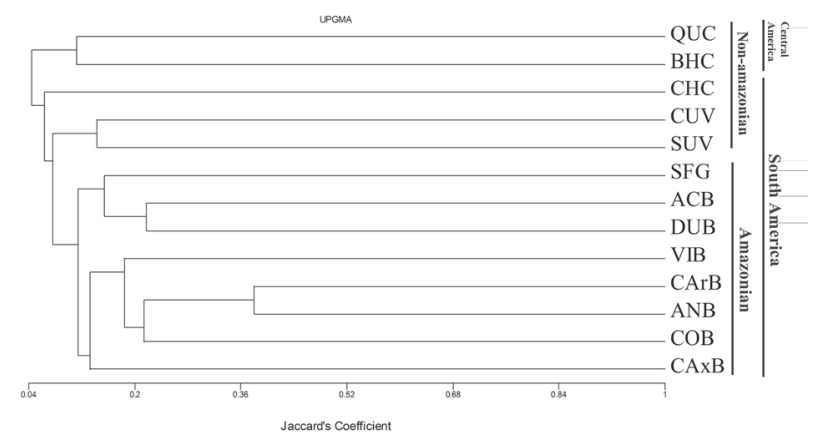

Figure 3. UPGMA analysis of floristic similarity of Orchidaceae species in northwestern South America and Costa Rica. The cluster matches some values of Jaccard index obtained from presence $\times$ absence data of species. 


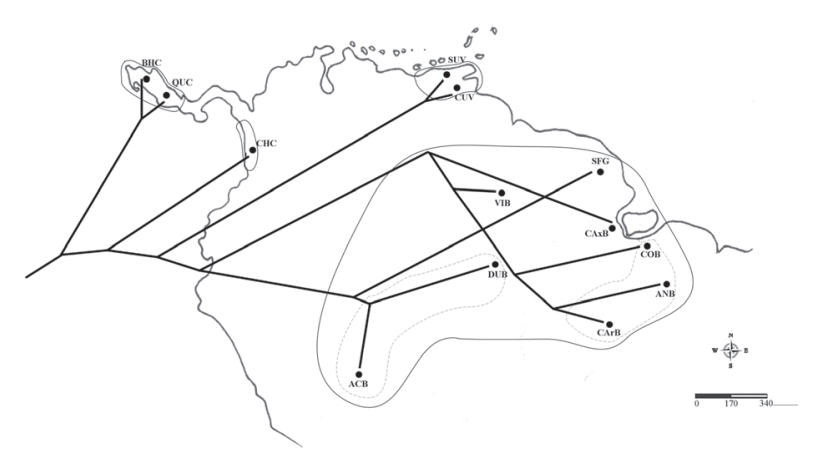

Figure 4. Map with a synthesis of the biogeographic pattern of the Orchidaceae distribution in northwestern South America and Costa Rica.

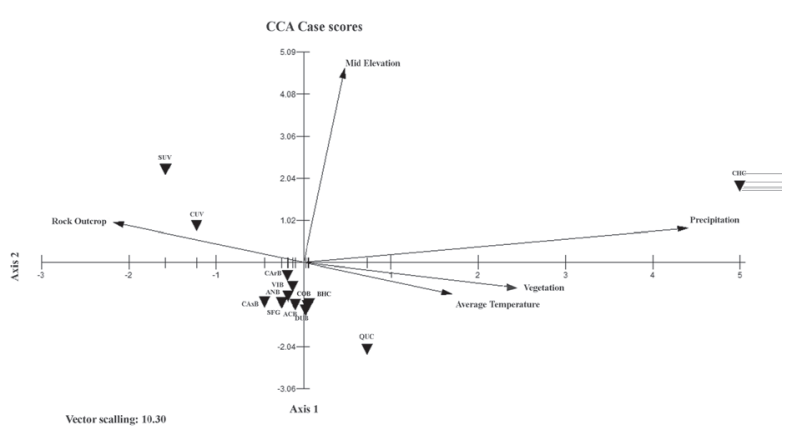

Figure 5: Ordination diagram representing the two first axes (Eigenvalues: Axis $1=73 \%$ and Axis $2=67 \%$; Canonic correlation: Axis $1=99 \%$ and Axis $2=98 \%$ ) generated by Canonic Correspondence Analysis for the study areas (triangles) and environmental conditions (arrows).

means they do not share a high level of common diversity in orchid composition. It may be due to the geographic position, because both areas are located on the border of the Guyana Shield. Those areas could be considered homologous to the border of ecosystems (contact zones), where plant diversity is a mix of influences from distinct ecosystems (Odum 1988).

As previously mentioned, the areas located in the Guyana Center of Endemism [Saül (SFG), Viruá (VIB) and Caxiunã $(\mathrm{CAxB})]$ do not settle in the same group in any of the analyses performed. Based upon the province subdivisions of Latin America suggested by Morrone (2006), through the methods of panbiogeography, they are part of three different bio-geographic provinces in South America with major differences in floristic composition and ecological features. Saül (SFG) would be part of the humid Guyana province, Viruá (VIB) in the Roraima province, and Caxiuanã (CaxB) in the Amapá province.

\section{Conclusions}

The analysis of the study areas showed the scarce knowledge we have regarding the orchid floristic composition in the western and central-eastern Amazon. We encourage further taxonomic studies in these regions.

The environmental conditions analyzed appear to be important factors to explain the orchid composition of areas outside the Amazon basin. Mid-elevation, precipitation, vegetation and average temperature distinguish the Costa Rican areas and the Chocó (Colombia), whereas the presence of rock outcrops distinguishes the Venezuelan areas.

The Amazonian group is environmentally very uniform, and no physical features were determinant of the internal segregation into two subgroups. Historical factors, which are the theory basis of the Endemism Centers, may explain the pattern shown.

Geographic closeness has no influence on the species composition arrangement for the areas studied. It could be explained by the large number of endemic species in the family, and the low percentage $(2.7 \%)$ of widely distributed species. Based on the analysis overview, the pattern observed is similar to several other studies with invertebrates, vertebrates and plants.

\section{Acknowledgements}

We are indebted to the organizations which funded our field research, including CNPq and CAPES (PNADB).

\section{Literature cited}

Ab'Sáber, A. 2006. Ecossistemas do Brasil. Metalivros, São Paulo.

Amorim, D.S. 2001. Dos Amazonias. In: J. L. Bousquets \& J. J. Morrone (eds). Introducción a la Biogeografía en Latinoamérica: Teorías, Conceptos, Métodos y Aplicaciones. Las prensas de Ciencias, Faculdad de Ciencias, UNAM, México, D.F., pp. 245-254.

Amorim, D.S. \& Pires, M.R.S. 1996. Neotropical biogeography and a method for maximum biodiversity estimation. In: C.E.M. Bicudo \& N.A. Menezes (eds.). Biodiversity in Brazil, a first approach. CNPq, São Paulo, pp. 183-219.

Atzingen, N.V., Cardoso, A.L.R. \& Ilkiu-Borges, A.L. 1996. Flora Orquidológica das Serras das Andorinhas, São Geraldo do Araguaia - PA. Boletim do Museu Paraense Emílio Goeldi, série botânica 12: 59-74. 
Baldwin, L.K. \& Bradfield, G.E. 2007. Bryophyte responses to fragmentation in temperate coastal rainforests: a functional group approach. Biological Conservation 136: 408-422.

Blanco, M.A., Carnevali, G., Whitten, W.M., Singer, R.B., Koehler, S., Williams, N.H., Ojeda, I., Neubig, K.M. \& Endara, L. 2007. Generic realignments in Maxillariinae (Orchidaceae). Lankesteriana 7: 515-537.

Bolker, B.M., Brooks, M.E., Clark, C.J., Geange, S.W., Poulsen, J.R., Stevens, M.H.H. \& White, J.S.S. 2009. Generalized linear mixed models: a practical guide for ecology and evolution. Trends in Ecology \& Evolution 24: 127-135.

Bogarín, D. \& Pupulin, F. 2007. Las orquídeas del Parque Nacional Barra Honda, Guanacaste, Costa Rica. Lankesteriana 7: 446-449.

Braem, R. 1993. Studies in the Oncidiinae - Discussion of some taxonomic problems with description of Gudrunia Braem. gen. nov., and reinstatement of the genus Lophiaris Rafinesque. Schlechteriana 4: 1-29.

Cardoso, A.L.R., Ilkiu-Borges, A.l. \& Suemitsu, C. 1996. Flora Orquidológica da Ilha Combu, Município de Acará - Pará. Boletim do Museu Paraense Emílio Goeldi, série botânica 12: 231-238.

Chase, M.W., Williams, N.H., Faria, A.D., Neubig, K.M., Amaral, M.C.E. \& Whitten, W.M. 2009. Floral convergence in Oncidiinae (Cymbidieae, Orchidaceae): an expanded concept of Gomesa and a new genus Nohawilliamsia. Annals of Botany 104: 387-402.

Christenson, E.A. 1997. Orchidaceae. In: S. Mori, G. Cremers, C. Gracie, J.J. Granville, M. Hoff, J.D. Mitchell (eds.). Guide to the vascular plants of Central French Guiana. Part 1. Memoirs of the New York Botanical Garden 76: 286-342.

Christenson, E.A. 1999. The return of Cohniella (Orchidaceae: Oncidiinae). Lindleyana 14: 176-177.

Christenson, E.A. 2004. Orchidaceae. In: N. Smith, S. Mori, A. Henderson, D. Stevenson \& S. Heald (eds.). Flowering Plants of the Neotropics. New York Botanical Garden, New York, pp. 465-468.

Christenson, E.A. 2008. Orchidaceae. In: D. Daly \& M. Silveira (eds.). Flora of Acre, Brazil. Editora da Universidade Federal do Acre, EDUFAC, Rio Branco, pp. 287-291.

Cracraft, J. \& Prum, R.O. 1988. Patterns and processes of diversification: speciation and historical congruence in some Neotropical birds. Evolution 42: 603-620.

Daly, D.C. \& Mitchell, J.D. 2000. Lowland vegetation of tropical South America - An Overview. In: D.L. Lentz. Imperfect Balance: Landscape transformations in the pre-Columbian Americas. Columbia University Press, New York, pp. 392-453.
Dick, C.W., Roubik, D.W., Gruber, K.F. \& Bermingham, E. 2004. Long-distance gene flow and cross-Andean dispersal of lowland rainforest bees (Apidae: Euglossini) revealed by comparative mitochondrial DNA phylogeography. Molecular Ecology 13: 3775-3785.

Dressler R.L. 1981. The orchids - natural history and classification. Harvard University Press, Cambridge.

Dressler, R.L. 1993. Phylogeny and classification of the orchid family. Dioscorides Press, Portland.

Dressler, R.L. 2005. How many orchid species? Selbyana 26: $155-158$.

Dressler, R.L., Whitten, W.M. \& Williams, N.H. 2004. Phylogenetic relationships of Scaphyglottis and related genera (Laeliinae: Orchidaceae) based on nrDNA ITS sequence data. Brittonia 56: 58-66.

Franco-Rosselli, P. \& Berg, C. 1997. Distributional patterns of Cecropia (Cecropiaceae): A panbiogeographic analysis. Caldasia 19: 285-296.

Funk,V.A. \& Hollowell, T. 2007. Introduction. In: V.A. Funk, T. Hollowell, P. Berry, C. Kelloff \& S.N. Alexander. Checklist of the Plants of the Guiana Shield (Venezuela: Amazonas, Bolivar, Delta Amacuro; Guiana, Suriname, Guiana Francesa). Contributions from the United States National Herbarium 55: 1-584.

Garda, A.A. \& Cannatella, D.C. 2007. Phylogeny and biogeography of paradoxal frogs (Anura, Hylidae, Pseudae) inferred from $12 \mathrm{~S}$ and $16 \mathrm{~S}$ mitochondrial DNA. Molecular Phylogenetics and Evolution 44: 104-114.

Gentry, A.H. 1982. Phytogeographic Patterns as Evidence for a Chocó Refuge. In: G.T. Prance (ed.). Biological diversification in the tropics. Columbia University Press, New York, pp. 112-136.

Gentry, A.H. \& Dodoson, C.H. 1987. Diversity and biogeography of the Neotropical vascular epiphytes. Annals of the Missouri Botanical Garden 74: 205-233.

Gutierrez, R.G. \& Mosquera, H.R. 2006. Estúdio de la diversidad de orquídeas y su conservación em el departamento del Chocó, Colômbia. Revista Institucional Universidad Tecnológica del Chocó 25: 65-73.

Haffer, J. \& Prance, G.T. 2001. Climatic forcing of evolution in Amazonia during the Cenozoic: on the refuge theory of biotic differentiation. Amazoniana 16: 579-607.

Hall, J.P.W. \& Harvey, D. 2002. The phylogeography of Amazonia revisited: new evidence from riodinid butterflies. Evolution 56: 1489-1497.

Hooghiemstra, H. \& Hammen, T.V.D. 2001. Desarrollo del bosque Húmedo Neotropical en el Neógeno y Cuaternário: La Hipótesis de los Refúgios. In: J.L. Bousquets \& J.J. Morrone (eds.). Introducción a la Biogeografía en Latinoamérica: Teorías, Conceptos, Métodos y Aplicaciones. Las prensas de Ciencias, Faculdad de Ciencias, UNAM, México, D.F, pp. 245-254. 
Iganci, J.R.V. \& Morim, M.P. 2012. Coleções botânicas para conservação: um estudo de caso em Abarema Pittier (Leguminosae, Mimosoideae). Revista Brasileira de Biociências 10: 164-170.

Koch, A.K., Santos, J.U., Ilkiu-Borges, A.L. 2014. Sinopse das Orchidaceae holoepífitas e hemiepífitas da Floresta Nacional de Caxiuanã, PA, Brasil. Hoehnea 41: 129-148 2014.

Kovach, W.L. 2000. MVSP A multi-variate statistical package for Windows, version 3.1. Kovach Computing Services, Penthraeth.

Kury,A.B., Aleixo, A., Bonaldo, A.B., Marino, A., Percequilo, A., Vireira, A.O., Marques, A.C., Peixoto, A.L., Cruz, B.A., Franco, B.D.G., Inácio, C.A., Bicudo, C.E.M., Lamas, C.E., Van-den-Berg, C., Magalhães, C., Barros, C.F., Umino, C.Y., Costa, D.P., Canhos, D.A.L., Hajdu, E., Kitajima, E.W., Fantinatti-Garboggini, F., Thompson, F.L., Straube, F.C., Peixoto, F.L., Melo, G.A., Lima, H.C., Zaher, H., Machado, I., Santos, I.A.S., Azevedo, J.L., Grazia, J., Dergam, J.A, Pirani, J.R., Sette, D., Maia, L.C., Melo, L.C.P., Simone, L.R., Couri, M.C., Barbosa, M.R.V., Menezes, M., Siqueira, M.F., Lopes, M.A., Stanton, M.., Hpkins, M., Seleghim, M.H.R., Simões, N., Peixoto, O.L., Toledo, P.M., Fonseca, R.L., Souza, R.D.F., Giovanni, R., Reis, R.E., Torres, R.A., Vazoller, F., Souza, S., Mello, S.C.M., Oliveira, V.M., Canhos, V.P., Coradin, V.R., Araújo, W.L., Thomas, W.W., Wosiack, W.B. 2006. Diretrizes e Estratégias para a modernização de coleções biológic., as brasileiras e a consolidação de sistemas integrados de informação sobre biodiversidade. Centro de Gestão e Estudos Estratégicos/Ministério da Ciência e Tecnologia, Brasília.

Legendre, P. 1993. Spatial autocorrelation: trouble or new paradigm? Ecology 74: 1659-1673.

Legendre, P. \& Legendre, L. 1998. Numerical ecology. Elsevier Science, Amsterdam.

Leopardi, C. 2010. Orquideoflórula de un sector de Seranía de La Cuchila, municipio Caripe, estado Monagas, Venezuela. Lankesteriana 9: 541-555.

Leopardi, C. \& Cumana, L.J. 2008. Listado de especies de la familia Orchidaceae para el estado Sucre, Venezuela. Lankesteriana 8: 93-103.

McCulloch, C.E. \& Searle, S.R. 2001. Generalized, Linear and Mixed Models. John Wiley and Sons Ltd, New York.

Morrone, J.J. 2004. Panbiogeografía, componentes bióticos y zonas de transición. Revista Brasileira de Entomologia 48: 149-162.

Morrone, J.J. 2006. Biogeographic areas and transition zones of Latin America and the Caribbean Islands based on panbiogeographic and cladistic analysis of the entomofauna. Annual Review of Entomology 51: 467-494.

Odum, E.P. 1988. Ecologia. Guanabara Koogan S.A., Rio de Janeiro.

Pennington, R.T., Prado, D.A., Pendry, C. 2000. Neotropical seasonally dry forest and Pleistocene vegetation changes. Journal of Biogeography 27: 261-273.
Pessoa, E. 2013. Orchidaceae no Parque Nacional do Viruá, RR, Brazil: Aspectos Taxonômicos e Biogeográficos. Dissertação de Mestrado, Universidade Federal de Pernambuco, Recife.

Prance, G.T. 1982. Forest refuges: evidence from woody angiosperms. In: G.T. Prance (ed.). Biological diversification in the tropics. Columbia University Press, New York, pp. 137-158.

Pridgeon, A.M. \& Chase, M.W. 2001. A phylogeny reclassification of Pleurothallidinae (Orchidaceae). Lindleyana 16: 235-271.

Pupulin, F. 1998. Orchid florula of Parque Nacional Manuel Antonio, Quepos, Costa Rica. Revista de Biologia Tropical 46: 961-1037.

Pupulin, F. 1999. A revision of the genus Trichocentrum (Orchidaceae-Oncidiinae). Lindleyana 10: 183-210.

Quijano-Abril, M.A., Callejas-Posada, R., MirandaEsquivel, R.D. 2006. Areas of endemism and distribution patterns for Neotropical Piper species (Piperaceae). Journal of Biogeography 33: 1266-1278.

Ribeiro, J.E.L.S. 1999. Orchidaceae. In: J.E.L.S. Ribeiro, M.J.G. Hopkins, A. Vicentini, C.A. Sothers, M.A.S. Costa, J.M. Brito, L.H.P. Martins, L.G. Lohmann, P.A.C.L. Assunção, E.C. Pereira, C.F. Silva, M.R. Mesquita \& L.C. Procópio. Flora da Reserva Ducke, Guia de identificação das plantas vasculares de uma floresta de terra-firme na Amazônia Central. INPA, Manaus, pp. 728-749.

Silva, J.M.C., Rylands, A.B. \& Fonseca, G.A.B. 2005. $\mathrm{O}$ destino das áreas de endemismo da Amazônia. Megadiversidade 1: 124-131.

Silveira, E.C., Cardoso, A.L.R., Ilkiu-Borges, A.L. \& Atzingen, N.V. 1995. Flora Orquidológica da Serra do Carajás, Estado do Pará. Boletim do Museu Paraense Emílio Goeldi, série botânica 11: 75-87.

Sneath, P.H.\& Sokal, R.R. 1973. Numerical taxonomy: The principles and practice of numerical classification. W.H.Freeman, San Francisco.

StatSoft Inc. 2004. Statistica (data analysis software system), version 7.0. Available in http://www.statsoft. com (access in 22-IX-2013).

Stehmann, J.R., Forzza, R.C., Sobral, M.\& Kamino, L.H.Y. 2009. Gimnospermas e Angiospermas. In: J.R. Stehmann, R.C. Forzza, A. Salino, M. Sobral, D.P. Costa \& L.H.Y. Kamino (eds.). Plantas da Floresta Atlântica. Jardim Botânico do Rio de Janeiro, Rio de Janeiro, pp. 27-37.

Ter Braak, C.J.F. 1987. The analysis of vegetation environment relationship by canonical correspondence analysis. Vegetatio 69: 69-77.

Trejo-Torres J.C. \& Ackerman, J.D. 2001. Biogeography of the Antilles based on parsimony analysis of orchid distributions. Journal of Biogeography 28: 775-794.

Van Der Pijl, L. \& Dodson, C.H. 1966. Orchid Flowers - their pollination and evolution. University of Miami Press, Miami. 